\title{
Kidney Schwannoma
}

National Cancer Institute

\section{Source}

National Cancer Institute. Kidney Schwannoma. NCI Thesaurus. Code C159221.

A rare schwannoma arising from the kidney. 